Western North American Naturalist 68(2), (C) 2008, pp. 138-152

\title{
RESPONSE OF ANTELOPE BITTERBRUSH SHRUBSTEPPE TO VARIATION IN LIVESTOCK GRAZING
}

\author{
P.G. Krannitz ${ }^{1}$
}

\begin{abstract}
Shrubsteppe ecosystems in the Intermountain West have suffered extreme alteration from a variety of factors. Using a retrospective approach, I studied the effects of horse and cattle grazing at the northern edge of the range in southern British Columbia, Canada, where the shrubsteppe is not as heavily altered and ungrazed sites remain in areas dominated by antelope bitterbrush (Purshia tridentata). I measured shrub and understory cover at 10 sites that were either ungrazed, lightly grazed, or heavily grazed. Cover of antelope bitterbrush decreased with grazing, and cover of big sagebrush (Artemisia tridentata) increased with grazing intensity. I sampled 72 species of vascular plants in the understory. Livestock grazing resulted in more bare soil, especially at sandy rather than rocky sites, and in quadrats located in the interspaces between shrubs. More bare soil was associated with less spikemoss (Selaginella spp.) and less microbiotic crust cover. Of the 3 most common bunchgrasses, sand dropseed (Sporobolus cryptandrus) was associated with more bare soil but only at sites without spikemoss. Red three-awn (Aristida purpurea var. longiseta), which grew best without litter or microbiotic crust, was most commonly found with spikemoss. Needle-and-thread grass (Hesperostipa comata), the most palatable abundant bunchgrass, was affected by livestock grazing, with shrub canopy cover offering some protection from grazers at the most heavily grazed sites. Rangeland management prescriptions in this area should take soil differences into account, with sandy soils being more prone to overgrazing and disturbance of the microbiotic crust cover than rocky soils.
\end{abstract}

Key words: bare soil, bitterbrush, grazing, Hesperostipa comata, sagebrush, Selaginella, Sporobolus cryptandrus, CANOCO, CCA.

In ungrazed and undisturbed conditions, shrubsteppe vegetation of the Intermountain region between the Rocky Mountains and the coastal mountain ranges is affected by soil and climatic differences, and consists of varying amounts and species of sagebrush (Artemisia spp.), other shrubs, perennial bunchgrasses, and lichen and moss cover (Daubenmire 1956, 1988, Vale 1975, West 1983, 1988). Being nonrhizomatous, bunchgrasses do not spread laterally following herbivory and do not respond positively to grazing (Daubenmire 1940, Mack and Thompson 1982). Widespread and heavy livestock grazing since European colonization altered this ecosystem considerably, with bunchgrasses in grazed areas often depleted within the first few decades of use (Mack 1981). Sagebrush might have increased in density in some areas, but historical accounts and photos show that shrubs have always been a dominant component of the landscape in the Intermountain region (Vale 1975, West 1988). In some areas bunchgrass cover was replaced by the invasive winter annual cheatgrass (Bromus tectorum), which spread throughout overgrazed shrubsteppe after being introduced through cultivation (Klemmedson and Smith 1964, Mack 1981). Shrubsteppe habitats in many locations were further degraded through mechanical or chemical treatments that removed sagebrush in an effort to establish introduced bunchgrasses such as crested wheatgrass (Agropyron desertorum) for continued grazing by livestock (Vale 1974, Shane et al. 1983). Given these largescale changes, it is not surprising that ecosystem processes have been altered, with fire frequencies changing from decadal periodicity in perennial shrubsteppe to the annual fire frequency of annual grasslands (D'Antonio and Vitousek 1992).

Shrubsteppe of the Intermountain West ranges as far north as southern Canada, through a narrow band along the Okanagan Valley in Washington State extending into more open rangeland near Kamloops, British Columbia (Mack 1981, Daubenmire 1988). Historical accounts show that shrubsteppe in Canada was severely overgrazed by the late 1800 s, with an 


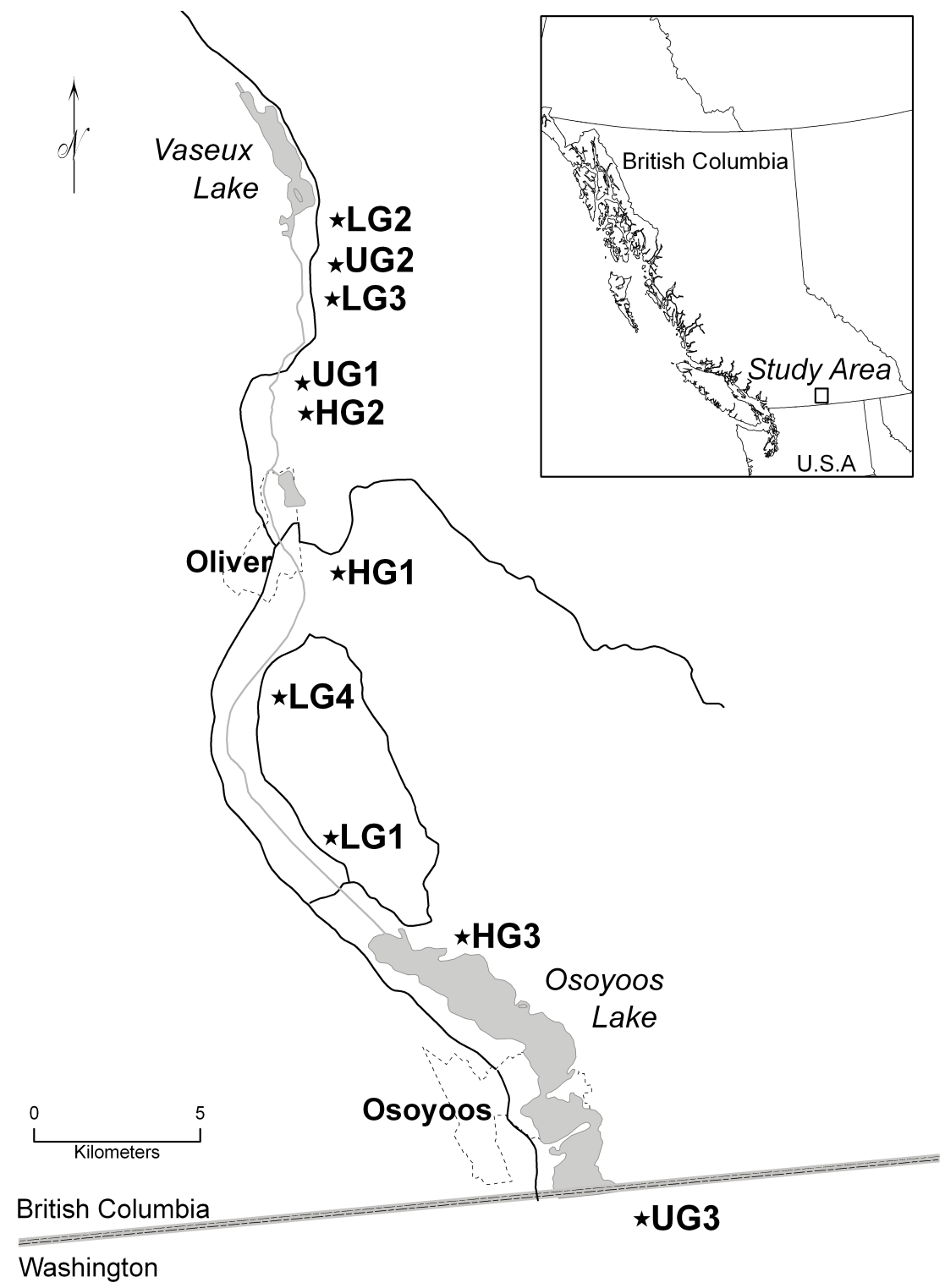

Fig. 1. Map of 10 sites in antelope bitterbrush (Purshia tridentata) shrubsteppe in southern Okanagan Valley, British Columbia, Canada, and Washington State.

invasion of cheatgrass accompanying this disturbance (Mack 1981). However, rangeland management commenced in the 1930s, with the establishment of grazing exclosures and research activities (McLean and Tisdale 1972), and the implementation of rotational grazing systems, which resulted in much improved range conditions (Bawtree 2005). Unlike some areas of shrubsteppe farther south, large areas of cheatgrass in British Columbia disappeared following improved management (Bawtree 2005).

The 1st objective of my study was to assess the effects of horse and cattle grazing on an extant shrubsteppe ecosystem at the northern edge of its range in the southern Okanagan Valley. My study is retrospective, comparing a range of grazing histories including 3 ungrazed sites, 2 of which were topographically isolated and not historically owned by ranchers. Apart 
from the northward cattle drive in the mid- to late 1800s (Bawtree 2005), these sites remained free from livestock grazing. My study was impossible to conduct in big sagebrush (Artemisia tridentata) steppe because there were no comparable ungrazed sites; consequently, all of my study sites were dominated by antelope bitterbrush (Purshia tridentata). It is known that antelope bitterbrush is palatable and resistant to browsing (Bilbrough and Richards 1993), but how it responds to historical grazing pressure is not known. I predicted that antelope bitterbrush would not increase in cover (\%) in response to grazing because (1) it is not disturbance adapted and (2) it has large seeds that are dispersed by rodents (Vander Wall 1994) and do not persist in the seed bank (Crist and Friese 1993, Clements et al. 2007).

The 2nd objective of my study was to evaluate the effect of shrub canopy cover on the understory plant community, which is likely to interact with the effects of grazing. In California, seedlings of coast live oak (Quercus agrifolia) were less browsed and established more readily under a shrub canopy (Callaway and D’Antonio 1991). Irrespective of livestock grazing, shrubs confer heterogeneity to a site in nutrients, moisture, and light (West 1989, Alpert and Mooney 1996). It is expected that this heterogeneity will affect the distribution of understory species (Gutiérrez et al. 1993) in interaction with their palatability to grazers and grazing pressure at a site.

\section{Study Sites}

Ecosystem classification is commonly used in British Columbia to assist with management of its diverse landbase (Banner et al. 1996). Polygons of habitat in the southern Okanagan and Similkameen Valleys were classified in 1991-1994 using Biophysical Mapping, a precursor to Terrain Ecosystem Mapping (TEM; Iverson and Haney 2006). There were 24 potential study sites, or polygons of $\geq 5 \mathrm{ha}$, on the east side of the Okanagan Valley with the same shrubsteppe vegetation classification and a variety of range conditions ("AN": antelope bitterbrush with needle-and-thread grass [Hesperostipa comata] and coarse-textured soils). Upon ground-truthing, I found 9 sites available for use in the southern Okanagan, and I added another site from adjacent Washington State (Fig. 1). The plant community at these sites was similar to that described as antelope bitterbrush/needle-and-thread grass in north central Washington (Youtie et al. 1988). Needle-and-thread grass is predicted to be the most abundant palatable bunchgrass (the "climax" species) at these coarse-soiled sites (McLean and Marchand 1968), while sand dropseed (Sporobolus cryptandrus) is the predicted "increaser" in response to livestock grazing (McLean and Marchand 1968). Average annual precipitation over the last 30 years for the weather station nearby at Oliver is 327.5 mm (data available from: http:// www.climate. weatheroffice.ec.gc.ca/climate_normals/index_ e.html).

The area of each sampled site ranged from 5 to 10 ha (Table 1). However, only site LG1 was alienated by cultivation on all sides; the rest were surrounded by large tracts of contiguous shrubsteppe and ponderosa pine (Pinus ponderosa) habitat (though site UGl was alienated by an irrigation canal). Other research from these sites has been published under different site names (UG1 - BW, UG2 - KB, UG3 - WA, LG1 - BO, LG2 - CWS, LG3 - KL, LG4 - OS, HG1 - WT, HG2 - RG, HG3 - OL or ELO; Krannitz 1997, Krannitz and Hicks 2000).

Soils were described by the biophysical maps and were partly based on soil maps from Wittneben (1986) and from sampling representative polygons on the ground. For most sites the soils were classified as Orthic Brown. Sites UG1, LG3, and HG2 had Orthic Dark Brown soils, with an "exceedingly stony surface." The "stones" consisted of river rock, commonly $20-30 \mathrm{~cm}$ in diameter, and were not solely on the surface. Soil texture for Orthic Brown and Orthic Dark Brown was a combination of loamy sand and sandy loam (Wittneben 1986). Only 1 site, UG2, had a different soil type, which was Rego Brown/Rego Dark Brown soil with a gravelly silt loam texture (Wittneben 1986).

\section{Methods}

\section{Historical and Current Grazing}

Horses and cattle were the dominant large herbivores grazing at the study sites. I combined use by horses and cattle to rank and group the 10 sites according to grazing because both horses and cattle consume grass and their diets in sagebrush rangeland in northern California did not differ (Hanley and Hanley 1982, 
Reiner and Urness 1982). I used anecdotal observations and frequency of dung in quadrats to determine use by horses and to determine recent (last 10 years) use by both horses and cattle. Presence of dung is an effective way to determine occupancy of a site by horses (Beever et al. 2003), and measures of dung or dropping frequency are linearly correlated to numbers of animals for species for which this has been determined (kangaroos [Setonix brachyurus], Hayward et al. 2005, and [Thylogdle stigmatica], Vernes 1999; rabbit [Sylvilagus palustris], Forys and Humphrey 1997; and feral swine [Sus scrofa], Engeman et al. 2001). Grazing histories by both horses and cattle were obtained from current and former owners and rangeland users, and from land-use memories provided by neighbors.

Sites classified as "ungrazed" have experienced little or no cattle or horse grazing since 1920 or earlier. Site UG1 was adjacent to a primary road to the west, and an irrigation canal to the east alienated it in 1920 from the larger grazed landbase of the Osoyoos Indian Reserve (established in 1858-1864). Site UG2 was located on a waterless bench with steep, rocky terrain to the east and steep, unstable slopes to the west. A path allowed access by the occasional cow or horseback rider for short periods of time. This resulted in a small amount of horse dung being deposited at the site $(1.8 \%$ of quadrats). Site UG3 was alienated from grazed big sagebrush rangelands by a steep slope to the east and by fruit orchards to the north and south. A paved road that intersected the property formed the western boundary of the site.

Sites classified as "lightly" grazed had limited use up until the 1980s and no use thereafter. Site LG1 was grazed in the late 1800s and early 1900s, but not since the 1970s. It had some horse dung (5\% of the quadrats), attributable to visitors on horseback. Site LG2 was grazed by cattle and horses until 1966 when it was purchased for conservation. Site LG3 was situated below site UG2 and supported a small herd of cattle until the 1980s. Site LG4 did not have easy access to water, but horses were observed feeding there and the site was a corridor for travel; $7.5 \%$ of its quadrats had horse dung.

Sites classified as "heavily" grazed were used intensively in the past and are used currently. All 3 sites were within the Osoyoos Indian Reserve, with roaming herds of horses and cat- tle at sites HG1 and HG3. Stocking rate for the landbase within which sites HG3 and HG1 were situated was approximately 4.9 AUM $\mathrm{ha}^{-1}$ (Aaron Stelkia personal communication, Osoyoos Indian Reserve) with year-round use until 1991 when 80 of 140 cattle were moved to higher range in June. According to McLean and Marchand (1968), a stocking rate of 5.5 $\mathrm{AUM} \cdot \mathrm{ha}^{-1}$ will result in poor range condition in dry bunchgrass sites at low elevation. For good range condition at these sites, a stocking rate of $1 \mathrm{AUM} \cdot \mathrm{ha}^{-1}$ is required (McLean and Marchand 1968). Though cattle had access to both HG3 and HG1, they were known to be at HG3 for more of the year and browsed antelope bitterbrush, causing a "hedged" appearance (Krannitz and Hicks 2000). Cattle were known to be at site HGl in the late summer and fall. Horse dung at site HGl was found in $32.5 \%$ of the quadrats. Site HG3 was the only site with cattle dung being deposited in the quadrats $(2.5 \%$ of the quadrats, with $12.5 \%$ of the quadrats at HG3 having horse dung). Site HG2 was on the other side of the irrigation canal from UG1. It was near a pond where a herd of about 15 horses was concentrated, depositing dung in $35 \%$ of the quadrats.

Browsing by deer might confound grazing by livestock, and all sites except HG3 had some use by mule deer (Odocoileus hemonius; Krannitz and Hicks 2000). California bighorn sheep (Ovis canadensis californiana) were observed at LG2 and HG2 and potentially had access to UG2 and LG3 (Krannitz and Hicks 2000).

\section{Data Collection}

From late May to early June 1994, I sampled ground and herbaceous cover (\%) at each site with forty $20 \times 50$-cm quadrats, which is the number of quadrats suggested by Daubenmire (1959) to sample the majority of the common species at a shrubsteppe site. I placed 1 quadrat every $10 \mathrm{~m}$ along one 400 -m northsouth transect at each site. I used a compass bearing to position the transect and to avoid subjective placement attributable to ground vegetation. I used species nomenclature in Douglas et al. (1994, 1998, 1999, 2000, 2001) to identify plant species. I recorded aerial cover $(\%)$ of understory vegetation using modified Daubenmire cover categories $(<1 \%, 1-5 \%$, $5-25 \%, 25-50 \%, 50-75 \%$, 75-95\%, 95-100\%). In addition, I measured basal diameter $(\mathrm{cm})$ and maximum height $(\mathrm{cm})$ of the most common 
perennial bunchgrasses showing no signs of herbivory from each quadrat. I defined basal diameter as the width of the bunch at the point of contact with the substrate, and maximum height as the length of the longest vegetative leaf.

Using line-intercept (Brower et al. 1989), I measured shrub canopy cover with 9-13 sixtymeter transects per site. Juvenile antelope bitterbrush seedlings $(<2.5 \mathrm{~cm}$ in stem diameter) were counted in fifteen $50-\mathrm{m}^{2}$ circular quadrats (4.0-m radius; Shatford 1997) to give density.

\section{Statistical Analysis}

I used a direct ordination, canonical correspondence analysis (CCA; ter Braak and Šmilauer 1998) to test the effect of independent variables (canopy cover, current livestock grazing pressure [cover (\%) of livestock dung], and cover [\%] of deer or sheep pellets, bare soil, and litter) on cover $(\%)$ of the understory vascular species, spikemoss (Selaginella densa and S. wallacei), and microbiotic crust. Direct ordinations such as CCA use both species and environmental data to determine the strength of the relationship between them (Palmer 1993, ter Braak and Šmilauer 1998). I added a blocking file of site identity to describe the nested nature of the quadrat data within sites and to prevent pseudoreplication. Hence, Monte Carlo randomizations were performed within each block (or site) to test the strength of the independent variables (ter Braak and Šmilauer 1998). Species found in only 1 quadrat were omitted from CCA analyses and rare species were downweighted to avoid undue influence on the ordinations (ter Braak and Šmilauer 1998). Cover (\%) data were $\log (\mathrm{X}+$ 1) transformed to improve distribution of the data (Lepš and Šmilauer 2003).

I used analysis of variance (ANOVA, PROC GLM; SAS Institute, Inc. 1990) to evaluate the effects of grazing history and shrub canopy cover on aerial cover $(\%)$ and basal diameter and maximum height $(\mathrm{cm})$ of the most common bunchgrasses (H. comata, S. cryptandrus, A. purpurea var. longiseta) and of a composite "bunchgrass" variable that included the common species and bluebunch wheatgrass (Pseudoroegneria spicata), Sandberg bluegrass (Poa secunda), junegrass (Koeleria macrantha), Idaho fescue (Festuca idahoensis), threadleaf sedge (Carex filifolia), and Scribner's witchgrass (Dichanthelium oligosanthes var. scribnerianum).
I also used ANOVA to test the effect of grazing history and shrub canopy cover on cover (\%) of alien invasive species (cheatgrass and diffuse knapweed [Centaurea diffusa]) and on ground variables, including cover $(\%)$ of bare soil, litter, and microbiotic crust.

To evaluate the effect of historical grazing in each ANOVA, I grouped grazing history into 3 classes: ungrazed, lightly grazed, and heavily grazed; the error term was site identity nested within grazing. The mean square of variance attributable to the interaction between shrub canopy cover and site was the error term for the interaction between grazing history and shrub canopy cover, and for both shrub canopy cover and site identity. I transformed percentage data with the arcsine square-root transformation before performing ANOVAs. Significant differences between means within response variables were tested with Fisher's least significant difference test (LSMEANS within PROC GLM; SAS Institute, Inc. 1990).

I used ANOVA to evaluate the effect of grazing history on linear cover (\%) of antelope bitterbrush and big sagebrush. The mean square of variance attributable to site (nested within grazing history) was used as the error term for the effect of grazing history (PROC GLM; SAS Institute, Inc. 1990). I used ANCOVA to evaluate the association between cover $(\%)$ of bare soil and other ground covers (microbiotic crust, spikemoss) while controlling for site differences (the independent factor). I used Type III sums of squares estimable functions (PROC GLM; SAS Institute, Inc. 1990), which consider the variation attributable to both the covariable and independent factor at the same time and hence adjust the covariation according to the site structure of the data. This analysis considered quadrats only in the interspace between shrubs.

Spearman's rank order correlations were used to evaluate associations between plant species' cover at a site and cover of litter, microbiotic crust, and bare soil (PROC CORR; SAS Institute, Inc., 1990). In this analysis I used site means from quadrats in the interspace because of the strong effect of canopy cover on understory plants. Recent livestock use (over the last 10 years) was estimated with frequency (\%) of dung in quadrats at each site. I also evaluated the effect of recent livestock use on linear canopy cover (\%) and other site characteristics 
TABLE 1. Site characteristics including number of quadrats located beneath the canopy of antelope bitterbrush (Purshia tridentata) and in shrub interspaces.

\begin{tabular}{|c|c|c|c|c|c|}
\hline \multirow[b]{2}{*}{ Site } & \multirow[b]{2}{*}{ Elevation (m) } & \multirow[b]{2}{*}{ Area (ha) } & \multirow[b]{2}{*}{$\%$ Shrub cover $\left(s_{\bar{x}}\right)$} & \multicolumn{2}{|c|}{ Number of quadrats } \\
\hline & & & & canopy & interspaces \\
\hline \multicolumn{6}{|c|}{ Ungrazed } \\
\hline UG1 & 336 & 8.2 & $32(3.8)$ & 11 & 29 \\
\hline UG2 & 452 & 5 & $24(1.9)$ & 9 & 31 \\
\hline UG3 & 355 & 10 & $31(2.8)$ & 13 & 27 \\
\hline \multicolumn{6}{|c|}{ Lightly grazed } \\
\hline LG1 & 352 & 8.75 & $25(2.1)$ & 7 & 33 \\
\hline LG2 & 371 & 10 & $36(6.5)$ & 17 & 23 \\
\hline LG3 & 340 & 5 & $49(3.1)$ & 13 & 27 \\
\hline LG4 & 369 & 5 & $44(7.4)$ & 16 & 24 \\
\hline \multicolumn{6}{|c|}{ Heavily grazed } \\
\hline HG1 & 476 & 7.5 & $22(2.7)$ & 9 & 31 \\
\hline HG2 & 339 & 10 & $21(4.2)$ & 9 & 31 \\
\hline HG3 & 356 & 5 & $28(2.3)$ & 11 & 29 \\
\hline
\end{tabular}

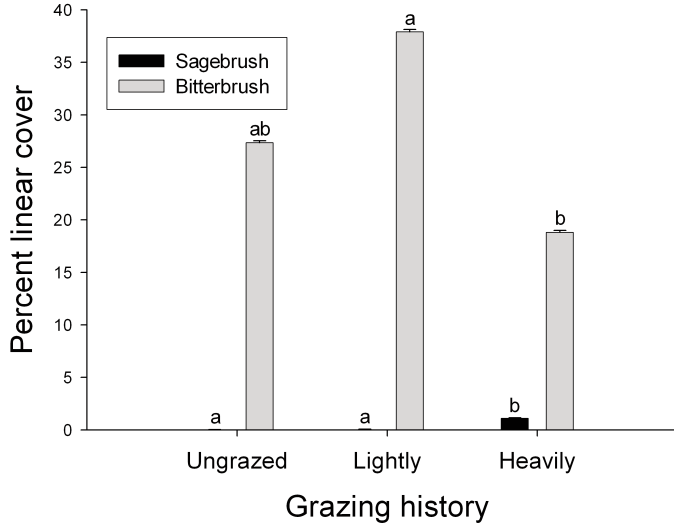

Fig. 2. Back-transformed LSMEANS of linear cover (\%) of antelope bitterbrush (Purshia tridentata) and big sagebrush (Artemisia tridentata) from an ANOVA on effects of grazing history adjusted for site differences. Means that do not share letters within a species are significantly different at $P \leq 0.05$. Error bars represent 1 standard error.

with Spearman's rank order correlation analysis (PROC CORR; SAS Institute, Inc. 1990).

\section{Results}

Total linear shrub cover at my study sites ranged from $21 \%$ to $49 \%$ (Table 1). Antelope bitterbrush was the dominant shrub at $82 \%$ to $99 \%$ of the shrub cover, with big sagebrush, red currant (Ribes cereus), rabbitbrush (Ericameria nauseosus var. speciosa), and juneberry (Amelanchier alnifolia) comprising the remaining cover. I sampled 72 species of vascular plants and 3 species of nonvascular plants including fragile fern (Cystopteris fragilis), spike- moss spp. (Selaginella densa and S. wallacei), and microbiotic crust (contact author for a complete list of species). Mean microbiotic crust cover in the shrub interspace ranged from a low of $10.5 \%\left(s_{\bar{x}}=2.9\right)$ at site UG1 to a high of $49.6 \%\left(s_{\bar{x}}=2.9\right)$ at site UG3 and consisted of lichen and moss species (Atwood 1998). The most frequently sampled vascular species were cheatgrass $(92 \%)$ and needle-and-thread grass $(45 \%)$. The 2 nd most frequently sampled bunchgrass was Sandberg bluegrass (31\%).

\section{Grazing Effects and Bare Soil}

Sites with heavier recent use had lower cover $(\%)$ of antelope bitterbrush $\left(r_{\mathrm{s}}=-0.63, P\right.$ $=0.05, n=10$ ). Heavily grazed sites had lower cover of bitterbrush than lightly grazed sites but not the ungrazed sites $\left(F_{2,7}=5.3, P=0.04\right.$; Fig. 2). Bitterbrush was also less dominant at heavily grazed sites, constituting $82 \%-88 \%$ of total shrub canopy cover compared to $92 \%-99 \%$ at lightly grazed or ungrazed sites $(t=6.09, \mathrm{df}$ $=8, P<0.001)$. Bitterbrush cover was lower at heavily grazed sites because they were being browsed, not because there was lower establishment. This was evident because neither current nor historical grazing was associated with density of adult shrubs (historical rank: $n$ $=10, r_{s}=-0.16, P=0.66$; dung frequency: $n$ $=10, r_{s}=-0.24, P=0.51$ ) or juveniles (historical rank: $n=10, r_{s}=-0.31, P=0.38$; dung frequency: $\left.n=10, r_{s}=0.29, P=0.42\right)$.

Big sagebrush increased in cover $(\%)$ at heavily grazed sites $\left(F_{2,7}=4.85, P=0.048\right.$; Fig. 2), though the differences were small (ungrazed: $\bar{x}=0.032 \%, s_{\bar{x}}=0.006 \%$; lightly 
TABLE 2. Mean $\left(s_{\bar{x}}\right)$ cover (\%) of bare soil, litter, alien invasives diffuse knapweed (Centaurea diffusa) and cheatgrass (Bromus tectorum), and bunchgrasses needle-and-thread (Hesperostipa comata), sand dropseed (Sporobolus cryptandrus), and red three-awn (Aristida purpurea var. longiseta) for quadrats located beneath antelope bitterbrush (Purshia tridentata) canopies and in shrub interspaces, at ungrazed, lightly grazed, or heavily grazed sites. Means were back-transformed from ANOVAs regarding effect of grazing history and were hence adjusted for site differences. See Table 1 for sites within each grazing treatment and for quadrat sample sizes. Means that do not share letters within a variable are significantly different at $P \geq 0.05$.

\begin{tabular}{lcclccccc}
\hline & \multicolumn{2}{c}{ Ungrazed } & & \multicolumn{2}{c}{ Lightly grazed } & & \multicolumn{2}{c}{ Heavily grazed } \\
\cline { 2 - 3 } Variable & Canopy & Interspace & & Canopy & Interspace & & Canopy & Interspace \\
\hline Bare soil & $0.27(0.34) \mathrm{a}$ & $2.7(0.13) \mathrm{a}$ & & $0.49(0.24) \mathrm{a}$ & $2.6(0.11) \mathrm{a}$ & & $1.22(0.39) \mathrm{a}$ & $19.8(0.12) \mathrm{b}$ \\
Litter & $55.4(0.59) \mathrm{c}$ & $19.9(0.22) \mathrm{ab}$ & & $29.9(0.41) \mathrm{b}$ & $27.4(0.18) \mathrm{b}$ & & $60.6(0.67) \mathrm{c}$ & $13.2(0.21) \mathrm{a}$ \\
Knapweed & $0.22(0.03) \mathrm{abc}$ & $0.03(0.01) \mathrm{a}$ & & $0.06(0.02) \mathrm{ab}$ & $0.57(0.01) \mathrm{c}$ & & $0.19(0.03) \mathrm{abc}$ & $0.38(0.01) \mathrm{bc}$ \\
Cheatgrass & $6.4(0.21) \mathrm{ab}$ & $5.1(0.08) \mathrm{ab}$ & & $6.2(0.14) \mathrm{ab}$ & $5.0(0.06) \mathrm{b}$ & & $11.8(0.23) \mathrm{a}$ & $4.7(0.07) \mathrm{b}$ \\
Needle-and-thread & $0.41(0.07) \mathrm{a}$ & $4.5(0.02) \mathrm{b}$ & & $0.23(0.04) \mathrm{a}$ & $1.3(0.02) \mathrm{ab}$ & & $3.0(0.07) \mathrm{ab}$ & $2.4(0.02) \mathrm{ab}$ \\
Sand dropseed & $0.008(0.14) \mathrm{b}$ & $0.53(0.05) \mathrm{b}$ & & $0.2(0.09) \mathrm{b}$ & $1.95(0.04) \mathrm{a}$ & & $0.13(0.15) \mathrm{b}$ & $3.1(0.05) \mathrm{a}$ \\
Red three-awn & $0.0(0.2) \mathrm{a}$ & $1.7(0.07) \mathrm{b}$ & & $0.12(0.14) \mathrm{ab}$ & $0.2(0.06) \mathrm{ab}$ & & $0.07(0.22) \mathrm{ab}$ & $0.88(0.07) \mathrm{ab}$ \\
\hline
\end{tabular}

TABLE 3. The effect of grazing history, site, and canopy cover on the cover (\%) of bare soil and litter. Sources of error mean squares used in calculation of $F$ values are indicated.

\begin{tabular}{|c|c|c|c|}
\hline Source & $\mathrm{df}$ & $F$ & $P$ \\
\hline \multicolumn{4}{|l|}{$\%$ cover of bare soil } \\
\hline A - grazing & 2,7 & $\mathrm{~A} / \mathrm{B} 1.55$ & 0.28 \\
\hline B - site (nested within grazing) & 7,7 & B/E 5.43 & 0.020 \\
\hline C - canopy cover & 1,7 & $\mathrm{C} / \mathrm{E} 23.01$ & 0.0020 \\
\hline D - grazing $\times$ canopy cover & 2,7 & $\mathrm{D} / \mathrm{E} 4.38$ & 0.058 \\
\hline E - canopy cover $\times$ site (grazing) & 7,380 & E/F 2.81 & 0.0073 \\
\hline $\mathrm{F}$ - residual error & 380 & & \\
\hline \multicolumn{4}{|l|}{$\%$ cover of litter } \\
\hline A - grazing & 2,7 & A/B 0.28 & 0.77 \\
\hline B - site (nested within grazing) & 7,7 & $\mathrm{~B} / \mathrm{E} 4.41$ & 0.034 \\
\hline C - canopy cover & 1,7 & C/E 36.1 & 0.0005 \\
\hline D - grazing * canopy cover & 2,7 & $\mathrm{D} / \mathrm{E} 9.17$ & 0.011 \\
\hline E - canopy cover * site (grazing) & 7,380 & E/F 2.02 & 0.052 \\
\hline $\mathrm{F}$ - residual error & 380 & & \\
\hline
\end{tabular}

TABLE 4. Results of Monte Carlo randomization tests of the strength of environmental variables in explaining the distribution of understory plant species.

\begin{tabular}{lccc}
\hline Variable & Lambda & $F$ & $P$ \\
\hline Bare soil & 0.07 & 9.50 & 0.002 \\
Litter & 0.07 & 9.11 & 0.002 \\
Shrub canopy versus interspace & 0.03 & 4.47 & 0.002 \\
Frequency of livestock dung & 0.01 & 1.06 & 0.400 \\
Frequency of deer/sheep droppings & 0.01 & 1.02 & 0.720 \\
\hline
\end{tabular}

grazed: $\bar{x}=0.006 \% s_{\bar{x}}=0.066 \%$; heavily grazed: $\left.\bar{x}=1.1 \%, s_{\bar{x}}=0.057 \%\right)$. Big sagebrush made up a greater proportion of the shrub canopy at heavily grazed sites (1.5\%-16\%) compared to lightly grazed and ungrazed sites $(0 \%-1.1 \% ; t=1.90, \mathrm{df}=8, P \leq 0.05)$.

Livestock grazing and shrub canopy cover interacted in their effect on cover $(\%)$ of litter (Table 3), with more litter under the shrub canopy and less litter at heavily grazed sites in the interspace (Table 2). At the same time cover $(\%)$ of bare soil in the interspace at heavily grazed sites was over 6 times that of other sites (Table 2). The effect of historical grazing on bare soil was marginally significant (Table 3) because the rocky and heavily grazed site (HG2) had comparably little bare soil $(5.06 \% \pm$ $1.73 \%$ compared to $24.9 \% \pm 4.55 \%$ at HGl and $46.6 \% \pm 4.80 \%$ at HG3 [sample sizes in Table 1, interspace quadrats]). HG2 was physically separated from the ungrazed rocky site UGl by an irrigation canal and though it is unlikely cattle grazed at site HG2, it was observed to be heavily used by horses. Only heavily grazed sites, irrespective of soil rockiness, had greater cover (\%) of bare soil than litter in the shrub interspace (Table 2). Despite differences in rockiness, bare soil was associated with both historical and current livestock grazing (Fig. 4) and affected distribution of plant species among sites in the CCA (Table 4, 


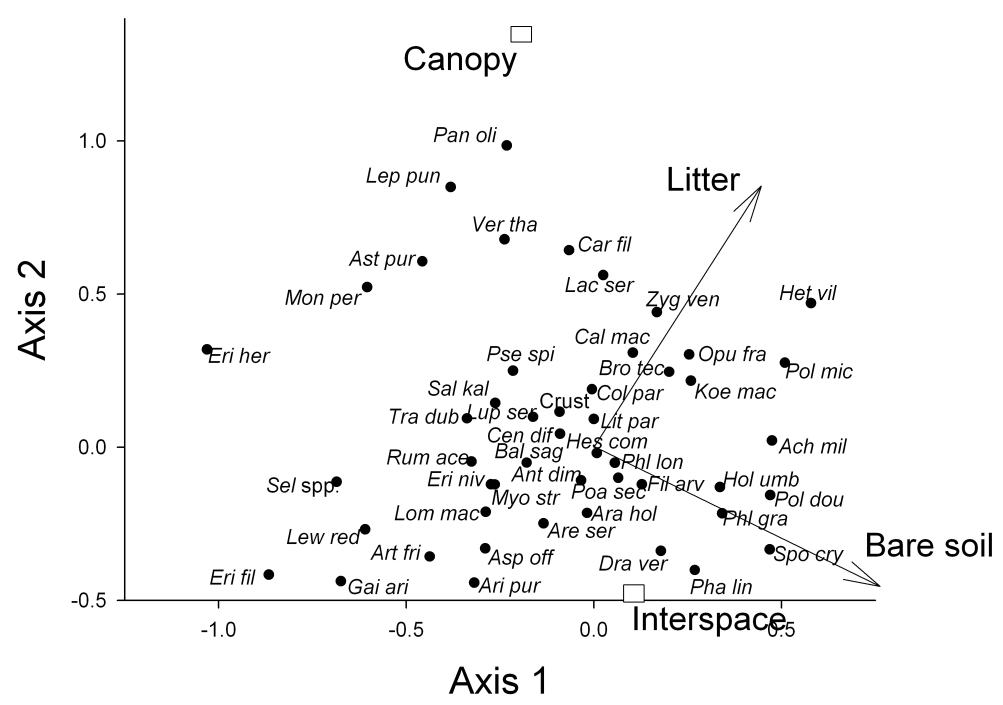

Fig. 3. Biplot of understory species and environmental variables associated with their distribution. Species codes consist of the first 3 letters of the genus and the first 3 letters of the specific epithet. For a complete list of the full species names, please contact the author. Nonsignificant variables are not shown (Table 4). Outliers were removed from the figure to improve resolution (Poa bulbosa, Crepis atrabarba, Silene latifolia ssp. alba, Artemisia tridentata, Mentzelia albicaulis, Poa pratensis, Ericameria nauseosus, Erigeron pumilis, Plantago patigonica, Vulpia octoflora).
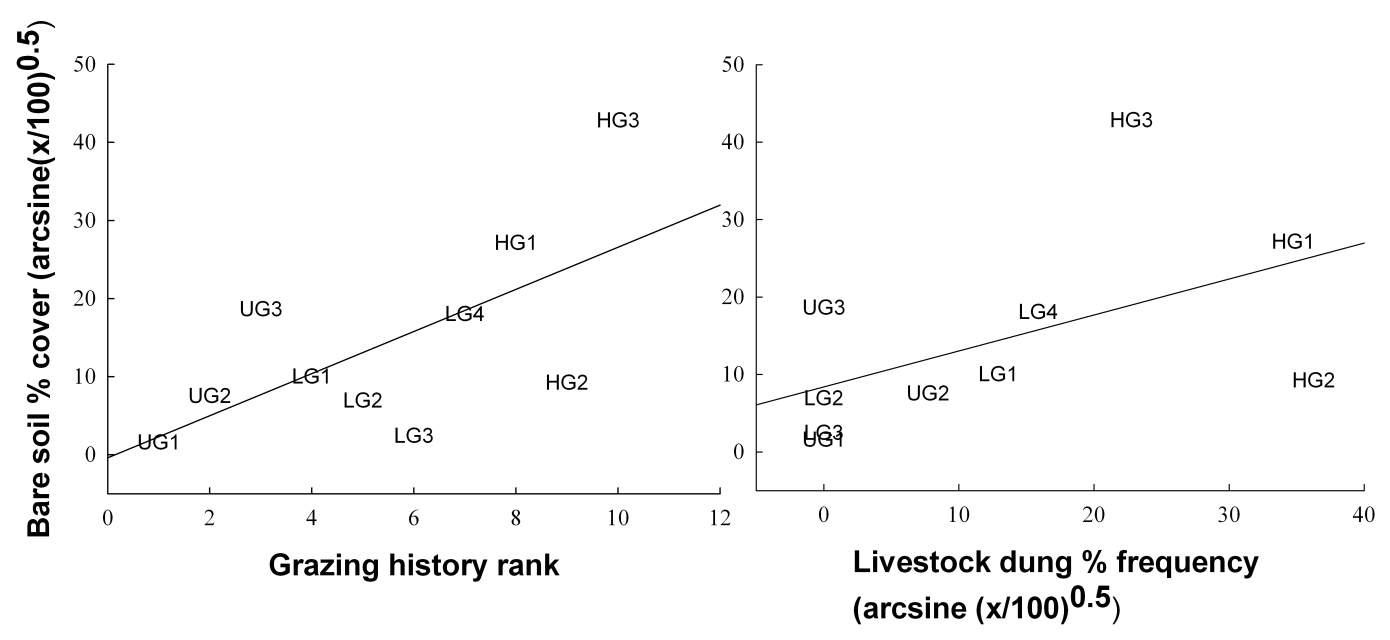

Fig. 4. Associations between cover $(\%)$ of bare soil and grazing history $\left(r_{s}=0.68, P=0.03\right)$ and current grazing pressure as measured by dung frequency $\left(r_{s}=0.71, P=0.02\right)$ at 10 sites in the southern Okanagan Valley, British Colombia. Site averages were calculated for quadrats located in shrub interspaces (sample sizes listed in Table 1 ).

Fig. 3). Cover (\%) of bare soil was also the dominant trend of axis $1(r=0.43)$. Current grazing by livestock, or use by deer or sheep, did not significantly affect distribution of the understory (Table 4).

Sand dropseed was positively associated with cover (\%) of bare soil in the CCA, while bluebunch wheatgrass was negatively associated
(Fig. 3). Bluebunch wheatgrass was uncommon in my study area; only 18 of 989 bunchgrasses were bluebunch wheatgrass, with 14 at ungrazed sites, 3 at lightly grazed, and 1 at heavily grazed sites.

Cover (\%) of bunchgrasses as a group did not decrease with heavier grazing (Fig. 5) and was not narrower in basal diameter (mean 
TABLE 5. F values $(\dagger P=0.063, * P \leq 0.05$, ** $P \leq 0.01$, *** $P \leq 0.001)$ from ANOVAs testing the effect of grazing history, canopy cover, site identity and their interactions on cover $\%$ of 3 bunchgrasses, needle-and-thread grass (Hesperostipa comata), sand dropseed (Sporobolus cryptandrus), and red three-awn (Aristida purpurea var. longiseta), and 2 alien invasive species, cheatgrass (Bromus tectorum) and diffuse knapweed (Centaurea diffusa). Error terms as in Table 3. Cover $(\%)$ data were arcsine square-root transformed prior to analysis.

\begin{tabular}{|c|c|c|c|c|c|}
\hline Species & Grazing & Canopy cover & Site identity & Grazing $\times$ canopy & Canopy $\times$ site \\
\hline Needle-and-thread & 1.49 & $15.74 * *$ & $6.53 * *$ & $7.48 *$ & 0.64 \\
\hline Sand dropseed & 1.36 & $17.01 * *$ & 1.91 & 0.78 & $2.00 *$ \\
\hline Red three-awn & 0.17 & $5.70^{*}$ & 1.83 & 1.52 & $2.65^{* * *}$ \\
\hline Cheatgrass & 0.28 & 4.23 & $3.42^{\dagger}$ & 1.26 & $3.02 * *$ \\
\hline Diffuse knapweed & 0.24 & 1.69 & $6.11 * *$ & $5.08 *$ & 0.62 \\
\hline
\end{tabular}

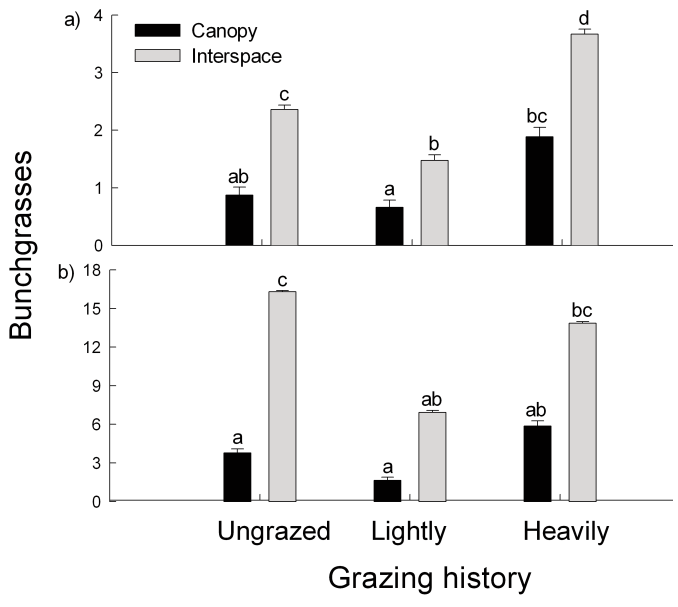

Fig. 5. Average density (per $\left.1000 \mathrm{~cm}^{2}\right)($ a) and cover $(\%)$ (b) (back-transformed from adjusted means from ANOVAs) for the bunchgrasses needle-and-thread (Hesperostipa comata), sand dropseed (Sporobolus cryptandrus), bluebunch wheatgrass (Pseudoroegneria spicata), red three-awn (Aristida purpurea var. longiseta), Sandberg bluegrass (Poa secunda), junegrass (Koeleria macrantha), Idaho fescue (Festuca idahoensis), threadleaf sedge (Carex filiformis), and Scribner's witchgrass (Dichanthelium oligosanthes var. scribnerianum). Quadrats were either under antelope bitterbrush (Purshia tridentata) canopies or in interspaces, at ungrazed, lightly grazed, or heavily grazed sites (see Table 1). Bars within a grazing history category that do not share letters were significantly different at $P \leq 0.05$. Error bars represent 1 standard error.

values: ungrazed $5.11 \mathrm{~cm}\left[s_{\bar{x}}=0.85, n=274\right]$, lightly grazed $5.08 \mathrm{~cm}\left[s_{\bar{x}}=0.89, n=274\right]$, heavily grazed $3.55 \mathrm{~cm}\left[s_{\bar{x}}=0.68, n=441\right]$; $\left.F_{2,7}=1.39, P=0.31\right)$. However, bunchgrasses were shorter at heavily grazed sites (mean values: ungrazed $25.55 \pm 3.13 \mathrm{~cm}$, lightly grazed $18.63 \pm 3.26 \mathrm{~cm}$, heavily grazed $12.67 \pm 2.53$ $\left.\mathrm{cm}\left[F_{2,7}=5.15, P=0.042\right]\right)$.

The relationship between cover $(\%)$ of sand dropseed and bare soil interacted with spikemoss. Among all 10 sites, sites with more bare soil did not have greater cover $(\%)$ of sand dropseed $\left(n=10, r_{s}=0.44, P=0.20\right)$. However, there was a strong association between cover (\%) of bare soil and sand dropseed among the 4 sites that did not have any spikemoss (HG 3, HG 1, UG 3, and LG $1 ; n=4, r_{s}$ $=1.0, P \leq 0.0001$ ).

Distribution of needle-and-thread grass was not associated with any variables in the CCA ordination and was located at the center of the ordination (Fig. 3). Grazing history and canopy cover interacted in their effect on cover $(\%)$ of needle-and-thread, increasing the variability of the response (Table 5). At heavily grazed sites, needle-and-thread did not differ in cover (\%) beneath or between antelope bitterbrush shrubs, whereas at ungrazed sites, cover (\%) was higher in the shrub interspace, similar to red three-awn and sand dropseed (Table 2). This pattern suggests that shrubs offered protection from grazing at grazed sites even though cover was not lower in the interspace.

Cover $(\%)$ of microbiotic crust and spikemoss decreased as that of bare soil increased with livestock grazing (Fig. 3 and Type III sums of squares ANCOVA results: spikemoss with bare soil, $F_{1,274}=6.6, P=0.01$; sites, $F_{1,274}=27.9, P<0.0001$; crust with bare soil, $F_{1,274}=17.8, P<0.0001$; sites, $F_{9,274}=9.2$, $P<0.0001)$. The same pattern was found for quadrats under the shrub canopy for cover $(\%)$ of crust (bare soil, $F_{1,104}=4.0, P<0.05$; sites, $\left.F_{9,104}=2.8, P=0.02\right)$, but not for cover (\%) of spikemoss (bare soil, $F_{1,104}=1.85, P=$ 0.2 ) except for significant differences between sites (sites, $F_{9,104}=6.75, P<0.0001$ ).

Other plant species associated with shrub interspaces and cover (\%) of bare soil were the annuals common draba (Draba verna), threadleaved phacelia (Phacelia linearis), Douglas' knotweed (Polygonum douglasii), pink twink 
(Phlox gracilis), jagged chickweed (Holosteum umbellatum), field cottonrose (Filago arvensis); and the perennials or biennials Sandberg bluegrass, long-leaved phlox (Phlox longifolia), Holboel's rockcress (Arabis holboellii), and low pussytoes (Antennaria dimorpha; Fig. 3). Red three-awn preferred sites with less microbiotic crust cover $\left(n=10, r_{s}=-0.80, P=0.0005\right)$, and quadrats with less litter (Fig. 3). It was most abundant at UG1, where it had $13.7 \%$ cover (next highest was $7.4 \%$ at HG2) and was strongly associated with spikemoss cover $(n=$ $29, r_{s}=0.58, P<0.001$ ).

\section{Understory and Litter}

The distribution of understory plant species was strongly influenced by shrub canopy cover (Table 4, Fig. 3). Crust cover (\%) was greater beneath canopies (Fig. $3 ; F_{1.7}=7.12 ; P=$ 0.032 ; canopy, $31.74 \% \pm 0.30 \%$; interspace, $18.96 \% \pm 0.24 \%)$, and there was more litter and less bare soil beneath canopies than in the interspace at ungrazed and heavily grazed sites (Tables 2, 3). Cover (\%) of litter $(r=0.43)$ and cover of shrub canopy $(r=0.44)$ were the dominant trends of axis 2 of the CCA.

The following species were associated with canopy cover and litter: the perennials bluebunch wheatgrass, sagebrush mariposa lily (Calochortus macrocarpus var. macrocarpus), sedge (Carex filiformis), death camus (Zygadenus venenosus), brittle prickly-pear cactus (Opuntia fragilis); the annuals small-flowered blue-eyed mary (Collinsia parviflora) and smallflowered woodland star (Lithophragma parviflorum var. parviflorum); and the aliens prickly lettuce (Lactuca serriola), great mullein (Verbascum thapsus), and cheatgrass (Fig. 3). Cheatgrass grew larger beneath shrub canopies as indicated by higher cover (\%; Table 2) but in similar densities between the interspace and beneath the shrub canopy (Krannitz unpublished data).

\section{DisCUSSION}

Livestock grazing directly affected the shrub canopy with a reduction in antelope bitterbrush and a slight increase in big sagebrush cover. Grazing also affected plants in the understory through an increase in the amount of bare soil at the expense of spikemoss and microbiotic crust. Compared with sandy soil sites, soils of rocky sites were not as disturbed from the effects of livestock grazing.

For antelope bitterbrush, reduction in shrub cover was not attributable to reduced establishment and was more likely because it is palatable and browsed by cattle (Reiner and Urness 1982, Krannitz and Hicks 2000). Up to $80 \%$ of bitterbrush shrubs in Oregon were browsed under heavy livestock grazing compared with 15\% under light grazing (Ganskopp et al. 2004). These authors showed an inverse relationship between the amount of forage available and the proportion of bitterbrush shrubs browsed, indicating that bitterbrush is not a preferred food for cattle. In contrast to ungulates, which browse bitterbrush in the winter, cattle browsed in the summer at site HG3, causing a hedged appearance in the plants (Krannitz and Hicks 2000). Horses were the dominant users at the other sites and they do not browse bitterbrush (Reiner and Urness 1982).

There were relatively small increases in big sagebrush cover after perhaps 100 years of grazing. This is consistent with studies that do not show an increase in big sagebrush over shorter periods of time (20 years; West and Yorks 2002) or a decrease in big sagebrush in grazing exclosures for 30 years or more (McLean and Tisdale 1972, Watts and Wambolt 1996). Although the increase in linear cover (\%) of sagebrush at heavily grazed sites was relatively small, the biological function changed, with the sagebrush-dependent songbirds Brewer's Sparrows visiting these predominantly bitterbrush sites (Krannitz 2007).

Cover of bare soil increased greatly at heavily grazed sites and strongly influenced the distribution of understory species. This effect has been shown in other semiarid ecosystems (Milchunas et al. 1989). In my study I found that soil rockiness interacted with grazing, with much less bare soil at the lightly and heavily grazed rocky sites LG3 and HG2. Rocky soils ("sheetwash alluvium") in New Mexico were also less affected by grazing than deeper soils ("deep alluvium"; Floyd et al. 2003). The amount of bare soil at the rocky and heavily grazed site HG2, and the consequent reduction in spikemoss cover, was consistent with reductions in dense spikemoss cover at rocky sites in Montana (Van Dyne and Vogel 1967). Similar to earlier findings (Anderson et al. 1982), microbiotic crust cover decreased as 
bare soil increased. This is likely because grazing at my sites occurred year-round, and crusts are more susceptible to disturbance in the growing season (Memmott et al. 1998).

It may be counterintuitive that cover $(\%)$ of bunchgrasses as a group did not increase while density increased at heavily grazed sites. However, the soil disturbance created by grazing may result in greater germination of disturbance-adapted species, though the plants may remain smaller. For example, the 2nd most frequent bunchgrass species in this study, Sandberg bluegrass, also increased in density (but not cover) with livestock grazing at shrubsteppe sites in Oregon (Rose et al. 1993). It is interesting that bunchgrasses at the heavily grazed sites were shorter, because this is a common response of rhizomatous grasses from the prairies that evolved with large grazers such as bison (Mack and Thompson 1982, Carman and Briske 1985). Shorter bluebunch wheatgrass was also found in Montana in grazed range (Fahnestock and Detling 2000) as was Idaho fescue in Wyoming (Pond 1960). Grasses could be shorter at heavily grazed sites for a variety of reasons, including "reduced vigor" from a loss of carbon (Weaver and Darland 1947, Pond 1960, Reece et al. 1988). Results from common garden experiments in which differences in stature were maintained after several years indicate at least partial underlying genetic differences (Painter et al. 1993), though measurements of genetic markers in grazed and ungrazed Idaho fescue did not show any differences (Matlaga and Karoly 2004).

The observed positive response of sand dropseed to disturbed sandy soils has been reported earlier, especially within the context of overgrazing (Archer and Bunch 1953). However, recent work suggests that it responds best to moderate levels of grazing (Fuhlendorf and Smiens 1997), and that heavier levels of grazing are detrimental to its establishment (Chambers and Norton 1993). These findings suggest that the connection between sand dropseed and grazing pressure is a loose one and that it is affected indirectly through the influence of livestock activity on soil disturbance. The interaction with spikemoss may indicate an interaction with soil properties because it has been shown that the soils of transects with dense spikemoss have less sand and more silt than transects without (Van Dyne and Vogel 1967) and have more nutrients (Krannitz unpublished data).

Needle-and-thread grass, the most abundant palatable bunchgrass, was the only common understory species whose cover was directly negatively affected by livestock grazing. The potential effect of grazing on needle-and-thread grass populations is substantiated by studies that have shown it to decrease in production under heavy grazing pressure (Laycock and Conrad 1981), to be severely affected by defoliation (Wright 1967, Reece et al. 1988), and to increase in cover $(\%)$ under protection from grazing (Pearson 1965, Bethanfalvay and Dakessian 1984). Needle-and-thread grass is also a preferred forage species for horses, which were abundant at my heavily grazed sites (Krysl et al. 1986, Crane et al. 1997). Tueller and Blackburn (1974) used frequency of needle-and-thread grass to indicate range condition or successional state across 23 sites in Nevada. They described a response to grazing pressure similar to that found in this study, with "surviving plants protected under shrubby species"; France (2005) confirmed that cattle very rarely graze under shrubs.

Cheatgrass is palatable to grazing animals in the spring, and Daubenmire (1940) observed that its patchy distribution within heavily grazed areas required consideration of other factors. My results suggest that characteristics associated with conditions under the shrub canopy, such as increased moisture, should be investigated, as cover of cheatgrass was greater under antelope bitterbrush. My findings are supported by a 20 -year study demonstrating that cheatgrass disappeared because of drought between 1989 and 1992 (West and Yorks 2002), and by a study showing desiccation to be a major source of mortality for cheatgrass in nearby Washington State (Mack and Pyke 1984). Soil texture can also be a factor, with less sand and more silt favoring cheatgrass invasion in Utah (Belnap and Phillips 2001).

The lack of a response of the invasive alien diffuse knapweed to grazing history is not surprising given the ability of this species to respond to a variety of disturbances (Roché and Roché 1999). Diffuse knapweed will invade ungrazed grasslands (Myers and Berube 1983, Lacey et al.1990), but experiments in which competing grasses were defoliated showed that its establishment and growth would 
potentially benefit from grazing of neighboring perennial grasses (Sheley et al. 1997).

It is not uncommon that some species prefer to grow under shrub canopies while others prefer shrub interspaces (Shmida and Whittaker 1981, Gutiérrez et al. 1993, Tielbörger and Kadmon 1995). Shrub interspaces offer more sunlight, and in my study the sites are drier (Atwood 1998). For the few species associated with shrub canopy cover, preference may be for microbiotic crust as it was more abundant under antelope bitterbrush shrubs. Crust cover at my sites moderates the moisture regime (Atwood 1998) and may facilitate seedling establishment for species less well adapted to drought.

Red three-awn cover was greater in areas with spikemoss, suggesting that edaphic factors might be most important to its establishment. There are no previous accounts of nutrient requirements for this species, and there is conflicting information on its response to competition (Fowler 1986a, 1986b). The inconsistency may be attributable to soil nutrient status being an unmeasured and important factor in how red three-awn is affected by competition. I also found red three-awn associated with quadrats with little or no litter, which is consistent with Fowler (1988).

\section{Management Implications}

My results indicate that managers setting stocking rates should take rockiness into account because less rocky soils will be more susceptible to disturbance from grazing. Normally, all 10 sites would be classified under "low elevation, dry bunchgrass" and be given similar range prescriptions, but the effect of grazing will differ based on soil characteristics. This assertion is supported by studies that also show an association between soil properties and plant distribution in the Rocky Mountains (Stohlgren et al. 1999), just north of my study area (Parsons et al. 1971), and in big sagebrush ecosystems in Oregon (Lentz and Simonson 1987) and Nevada (Jensen et al. 1990). Sites with sandy soils are more susceptible to overgrazing and soil disturbance than rocky sites with spikemoss as the main ground cover. Associated with a decline in palatable species with high levels of grazing, the concomitant increase in soil disturbance on sandier sites will affect plant species associated with bare soil.

\section{ACKNOWLEDGMENTS}

I gratefully acknowledge landowners who permitted access to their land: Osoyoos Indian Band (LG4, HG1, HG3, HG2, UG1), Canadian Wildlife Service (LG2), BC Ministry of Environment (LG1), the Kennedy family (LG3, UG2), the Klein family (UG2), and Puget Properties, Inc. (UG3). Funding was provided by Environment Canada, Habitat Conservation Trust Fund, Human Resources Development Canada, Vancouver Foundation, and Endangered Species Recovery Fund. I greatly appreciate the technical assistance from Bruce Bennett, Jeff Shatford, Lynne Atwood, and Samantha Hicks. Statistical advice was generously provided by Anton Kozak, and comments from Elsie Krebs, Jeffrey L. Beck, Mark C. Belk, and 2 anonymous reviewers improved an earlier version of the manuscript.

\section{Literature Cited}

Alpert, P., AND H.A. MoOnEy. 1996. Resource heterogeneity generated by shrubs and topography on coastal sand dunes. Vegetatio 122:83-93.

Anderson, D.C., K.T. Harper, and S.R. Rushforth. 1982. Recovery of cyptogamic soil crusts from grazing on Utah winter ranges. Journal of Range Management 35:355-359.

ArCher, G., AND C.E. BunCH. 1953. The American grass book. University of Oklahoma Press, Norman.

ATwOOD, L.B. 1998. Ecology of the microbiotic crust of the antelope-brush (Purshia tridentata) shrub-steppe of the south Okanagan, British Columbia. Master's thesis, University of British Columbia, Vancouver, Canada.

Banner, A., D.V. Meidinger, E.C. Lea, R.E. Maxwell, AND B.C. VON SACKEN. 1996. Ecosystem mapping methods for British Columbia. Environmental Monitoring and Assessment 39:97-117.

BawtreE, A.H. 2005. A history of range use in British Columbia. Rangelands 27:36-39.

Beever, E.A., R.J. Tausch, and P.F. Brussard. 2003. Characterizing grazing disturbance in semiarid ecosystems across broad scales, using diverse indices. Ecological Applications 13:119-136.

Belnap, J., AND S.L. Phillips. 2001. Soil biota in an ungrazed grassland: response to annual grass (Bromus tectorum) invasion. Ecological Applications 11:12611275.

Bethanfalvay, G.J., and S. Dakessian. 1984. Grazing effects on mycorrhizal colonization and floristic composition of the vegetation on a semiarid range in northern Nevada. Journal of Range Management 37: 312-316.

Bilbrough, C.J., And J.H. Richards. 1993. Growth of sagebrush and bitterbrush following simulated winter browsing: mechanisms of tolerance. Ecology 74: 481-492. 
Brower, J.E., J.H. Zar, and C.N. von Ende. 1989. Field and laboratory methods for general ecology. 3rd edition. William C. Brown Publishers, Dubuque, IA.

Callaway, R.M., and C.M. D’Antonio. 1991. Shrub facilitation of coast live oak in central California. Madroño 38:158-169.

Carman, J.G., And D.D. Briske. 1985. Morphological and allozymic variation between long-term grazed and non-grazed populations of the bunchgrass Schizachyrium scoparium var. frequens. Oecologia 66:332337.

Chambers, J.C., AND B.E. Norton. 1993. Effects of grazing and drought on population dynamics of salt desert shrub species on the Desert Experimental Range, Utah. Journal of Arid Environments 24:261-275.

Clements, D.R., P.G. Krannitz, and S.M. Gillespie. 2007. Seed bank responses to grazing history by invasive and native plant species in a semi-desert shrub-steppe environment. Northwest Science 81:3749.

Crane, K.K., M.A. Smith, and D. Reynolds. 1997. Habitat selection patterns of feral horses in southcentral Wyoming. Journal of Range Management 50:374-380.

Crist, T.O., AND C.F. Friese. 1993. The impact of fungi on soil seeds: implications for plants and granivores in a semiarid shrub-steppe. Ecology 74:2231-2239.

D’Antonio, C.M., AND P.M. Vitousek. 1992. Biological invasions by exotic grasses, the grass/fire cycle, and global change. Annual Review of Ecology and Systematics 23:63-87.

Daubenmire, R.F. 1940. Plant succession due to overgrazing in the Agropyron bunchgrass prairie of southeastern Washington. Ecology 21:55-64.

1956. Climate as a determinant of vegetation distribution in eastern Washington and northern Idaho. Ecological Monographs 26:131-154.

1959. A canopy-coverage method of vegetational analysis. Northwest Science 33:43-64.

1988. Steppe vegetation of Washington. Washington State University Cooperative Extension, Pullman.

Douglas, G.W., D. Meidinger, and J. Pojar. 1999, 2000 2001. Illustrated flora of British Columbia. Volumes 3, 4, 5, and 6. Province of British Columbia, Victoria, Canada.

Douglas, G.W., G.B. Straley, and D. Meidinger. 1994. The vascular plants of British Columbia. Part 4, Monocotyledons. Province of British Columbia, Victoria, Canada.

Douglas, G.W., G.B. Straley, D. Meidinger, and J. POJAR. 1998. Illustrated flora of British Columbia. Volumes 1 and 2. Province of British Columbia, Victoria, Canada.

Engeman, R.M., B. Constantin, M. Nelson, and J. WOOLARD. 2001. Monitoring changes in feral swine abundance and spatial distribution. Environmental Conservation 28:235-240.

Fahnestock, J.T., and J.K. Detling. 2000. Morphological and physiological responses of perennial grasses to long-term grazing in the Pryor Mountains, Montana. American Midland Naturalist 143:312-320.

Floyd, M.L., T.L. Fleischner, D. Hanna, and P. WhiteFIELD. 2003. Effects of historic livestock grazing on vegetation at Chaco Culture National Historic Park, New Mexico. Conservation Biology 17:1703-1711.

Forys, E.A., AND S.R. HuMPHREY. 1997. Comparison of two methods to estimate density of an endangered lagomorph. Journal of Wildlife Management 61:86-92.
FowLER, N.L. 1986a. Microsite requirements for germination and establishment of three grass species. American Midland Naturalist 115:131-145.

1986b. Density-dependent population regulation in a Texas grassland. Ecology 67:545-554. 1988. What is a safe site? Neighbor, litter, germination date, and patch effects. Ecology 69:947-961.

France, K.A. 2005. Interspace/under-canopy foraging patterns of beef cattle in sagebrush communities: implications to sage-grouse nesting habitat. Master's thesis, Oregon State University, Corvallis.

Fuhlendorf, S.D., And F.E. SMeIns. 1997. Long-term vegetation dynamics mediated by herbivores, weather and fire in a Juniperus-Quercus savanna. Journal of Vegetation Science 8:819-828.

Ganskopp, D., T. Svejcar, F. Taylor, and J. Farstvedt. 2004. Can spring cattle grazing among young bitterbrush stimulate shrub growth? Journal of Range Management 57:161-168.

Gutiérrez, J.R., P.L. Meserve, L.C. Contreras, H. VÁsQUEZ, AND F.M. JAKSIC. 1993. Spatial distribution of soil nutrients and ephemeral plants underneath and outside the canopy of Porlieria chilensis shrubs (Zygophyllaceae) in arid coastal Chile. Oecologia 95:347-352.

Hanley, T.A., AND K.A. Hanley. 1982. Food resource partitioning by sympatric ungulates on Great Basin rangeland. Journal of Range Management 35:152158.

Hayward, M.W., P.J. De Tores, M.J. Dillon, B.J. Fox, AND P.B. BANKS. 2005. Using faecal pellet counts along transects to estimate quokka (Setonix brachyurus) population density. Wildlife Research 32:503507.

Iverson, K., AND A. Haney. 2006. Updated terrestrial ecosystem mapping (TEM) for the South Okanagan Valley (with sensitive ecosystems inventory [S.E.I.]). British Columbia Ministry of Environment. Victoria, Canada.

Jensen, M.E., G.H. Simonson, And M. Dosskey. 1990. Correlation between soils and sagebrush-dominated plant communities of northeastern Nevada. Soil Science Society of America Journal 54:902-910.

Klemmedson, J.O., And J.G. Smith. 1964. Cheatgrass (Bromus tectorum L.). Botanical Review 30:226262.

KranNitZ, P.G. 1997. Seed weight variability of antelope bitterbrush (Purshia tridentata: Rosaceae). American Midland Naturalist 138:306-321.

2007. Abundance and diversity of shrub-steppe birds in relation to encroachment of ponderosa pine. Wilson Journal of Ornithology. 119:655-664.

Krannitz, P.G., and S.L. Hicks. 2000. Browsing of Purshia tridentata (Purshia tridentata: Rosaceae) in the south Okanagan Valley, British Columbia: age preferences and seasonal differences. American Midland Naturalist 144:109-122.

Krysl, L.J., M.A. Smith, B.F. Sowell, M.E. Hubbert, G.E. Plumb, and J.W. Waggoner. 1986. Impact of feral horses on vegetation in the cold desert biome, U.S.A. Pages 569-570 in P.J. Joss, P.W. Lynch, and O.B. Williams, editors, Rangelands: a resource under siege, proceedings of the second International Rangeland Congress. Cambridge University Press, Cambridge, England.

Lacey, J., P. Husby, and G. Handl. 1990. Observations on spotted and diffuse knapweed invasion into ungrazed 
bunchgrass communities in western Montana. Rangelands 12:30-32.

Laycock, W.A., AND P.W. Conrad. 1981. Responses of vegetation and cattle to various systems of grazing on seeded and native mountain rangelands in eastern Utah. Journal of Range Management 34:52-58.

LENTZ, R.D., AND G.H. SimONSON. 1987. Correspondence of soil properties and classification units with sagebrush communities in southeastern Oregon: I. Comparisons between mono-taxa soil-vegetation units. Soil Society of America Journal 51:1263-1271.

LEPŠ, J., AND P. ŠMILAUER. 2003. Multivariate analysis of ecological data using CANOCO. Cambridge University Press, Cambridge, England.

MACK, R.N. 1981. Invasion of Bromus tectorum L. into western North America: an ecological chronicle. AgroEcosystems 7:145-165.

Mack, R.N., And D.A. Pyke. 1984. The demography of Bromus tectorum: the role of microclimate, grazing and disease. Journal of Ecology 72:731-748.

Mack, R.N., AND J.N. ThOMPsOn. 1982. Evolution in steppe with few large, hoofed mammals. American Naturalist 119:757-773.

Matlaga, D., AND K. Karoly. 2004. Long-term grazing effects on genetic variation in Idaho fescue. Journal of Range Management 57:275-279.

McLean, A., AND L. Marchand. 1968. Grassland ranges in the southern interior of British Columbia. Publication 1319. Canadian Department of Agriculture, Ottawa, Canada.

McLean, A., And E.W. Tisdale. 1972. Recovery rate of depleted range sites under protection from grazing. Journal of Range Management 25:178-184.

Memmott, K.L., V.J. Anderson, and S.B. Monsen. 1998. Seasonal grazing impact on cryptogamic crusts in a cold desert ecosystem. Journal of Range Management 51:547-550.

Milchunas, D.G., W.K. Lauenroth, P.L. Chapman, and M.K. KazEMPour. 1989. Effects of grazing, topography, and precipitation on the structure of a semiarid grassland. Vegetatio 80:11-23.

Myers, J.H., And D.E. Berube. 1983. Diffuse knapweed invasion into rangeland in the dry interior of British Columbia. Canadian Journal of Plant Science 63:981987.

Painter, E.L., J.K. Detling, and D.A. Steingraeber. 1993. Plant morphology and grazing history: relationships between native grasses and herbivores. Vegetatio 106:37-62.

Palmer, M.W. 1993. Putting things in even better order: the advantages of canonical correspondence analysis. Ecology 74:2215-2230.

Parsons, DC., L.M. Lavkulich, and A.L. van Ryswyk. 1971. Soil properties affecting the vegetative composition of Agropyron communities at Kamloops, British Columbia. Canadian Journal of Soil Science 51:269276.

Pearson, L.C. 1965. Primary production in grazed and ungrazed desert communities of eastern Idaho. Ecology 46:278-285.

Pond, F.W. 1960. Vigor of Idaho fescue in relation to different grazing intensities. Journal of Range Management 13:28-30.

ReEce, P.E., R.P. Bode, ANd S.S. WaLLer. 1988. Vigor of needleandthread and blue grama after short duration grazing. Journal of Range Management 41:287-291.
Reiner, R.J., and P.J. Urness. 1982. Effect of grazing horses managed as manipulators of big game range. Journal of Range Management 35:567-571.

Roché, B.F., JR., AND C.T. Roché. 1999. Diffuse knapweed. Pages 217-230 in R.L. Sheley and J.K. Petroff, editors, Biology and management of noxious rangeland weeds. Oregon State University Press, Corvallis.

Rose, J., R. Miller, and T. Svejcar. 1993. Vegetation change in response to 56 years of livestock exclusion. Pages 55-58 in Eastern Oregon Agricultural Research Center Annual Report, Special Report 923. Agricultural Experiment Station, Oregon State University Press, Corvallis.

SAS Institute, Inc. 1990. SAS user's guide. Volume 2. 4th edition. Cary, NC.

Shane, R.L., J.R. GarRetT, and G.S. Lucier. 1983. Relationship between selected factors and internal rate of return from sagebrush removal and seeding crested wheatgrass. Journal of Range Management 36:782-786.

SHATFORD, J.P. 1997. Seed dispersal, seed attributes and edaphic factors: their role and impact on the regeneration of antelope bitterbrush (Purshia tridentata). Master's thesis, University of British Columbia, Vancouver, Canada.

SHELEY, R.L., B.E. Olson, and L.L. LaRSON. 1997. Effect of weed seed rate and grass defoliation level on diffuse knapweed. Journal of Range Management 50: $39-43$.

Shmida, A., AND R.H. WhitTaKer. 1981. Pattern and biological microsite effects in two shrub communities, southern California. Ecology 62:234-251.

Stohlgren, T.J., L.D. Schell, and B. Vanden Heuvel. 1999. How grazing and soil quality affect native and exotic plant diversity in Rocky Mountain grasslands. Ecological Applications 9:45-64.

ter Braak, C.J.F., and P. Šmilauer. 1998. CANOCO reference manual and user's guide to CANOCO for windows: software for canonical community ordination. Version 4. Microcomputer Power, Ithaca, NY.

TielbÖRgER, K., AND R. KADMON. 1995. Effect of shrubs on emergence, survival and fecundity of four coexisting annual species in a sandy desert ecosystem. Ecoscience 2:141-147.

Tueller, P.T., and W.H. Blackburn. 1974. Condition and trend of the big sagebrush/needle-and-thread habitat type in Nevada. Journal of Range Management 27:36-40.

VALE, T.R. 1974. Sagebrush conversion projects: an element of contemporary environment change in the western United States. Biological Conservation 6:274-284.

1975. Presettlement vegetation in the sagebrushgrass area of the Intermountain West. Journal of Range Management 28:32-36.

Vander WaLL, S.B. 1994. Seed fate pathways of Purshia tridentata: dispersal by seed-caching yellow pine chipmunks. Ecology 75:1911-1926.

Van Dyne, G.M., AND W.G. Vogel. 1967. Relation of Selaginella densa to site, grazing, and climate. Ecology 48:438-444.

Vernes, K. 1999. Pellet counts to estimate density of a rainforest kangaroo. Wildlife Society Bulletin 27:991996.

WatTs, M.J., AND C.L. Wambolt. 1996. Long-term recovery of Wyoming big sagebrush after four treatments. Journal of Environmental Management 46:95-102. 
Weaver, J.E., and R.W. Darland. 1947. A method for measuring vigor in range grasses. Ecology 28:146164 .

WEST, N.E. 1983. Western Intermountain sagebrush steppe. Pages 351-374 in N.E. West, editor. Temperate deserts and semi-deserts. Elsevier Scientific Publishing Company, Amsterdam, The Netherlands.

1988. Intermountain deserts, shrub steppes and woodlands. Pages 209-230 in M.G. Barbourm and W.D. Billings, editors, North American terrestrial vegetation. Cambridge University Press, New York.

1989. Spatial pattern-functional interactions in shrub-dominated plant communities. Pages 283-305 in C.M. McKell, editor, The biology and utilization of shrubs. Academic Press, San Diego, CA.

West, N.E., AND T.P. YoRKs. 2002. Vegetation responses following wildfire on grazed and ungrazed sage- brush semi-desert. Journal of Range Management 55:171-181.

Wittneben, U. 1986. Soils of the Okanagan and Similkameen Valleys. Report No. 52, British Columbia Soil Survey. British Columbia Ministry of the Environment, Victoria, Canada.

WrighT, H.A. 1967. Contrasting responses of squirrel tail and needle-and-thread to herbage removal. Journal of Range Management 20:398-401.

Youtie, B.A., B. Griffith, and J.M. Peek. 1988. Successional patterns in bitterbrush habitat types in northcentral Washington. Journal of Range Management 41:122-126.

Received 1 September 2006 Accepted 18 December 2007 